\title{
Exposure assessment and lung function in pig and poultry farmers
}

\author{
K Radon, C Weber, M Iversen, B Danuser, S Pedersen, D Nowak
}

Institute of

Occupational and

Environmental

Medicine,

Ludwig-Maximilians-

University, Innenstadt,

Ziemssenstrasse 1,

D-80336, München,

Germany

K Radon

D Nowak

Institute of Hygiene

and Applied

Physiology, ETH

Zurich, Switzerland

C Weber

B Danuser

Aarhus University

Hospital, Department

of Respiratory

Diseases, Aarhus,

Denmark

M Iversen

Research Centre

Bygholm, Horsens,

Denmark

S Pedersen

Correspondence to:

Dr K Radon

Katja.Radon@arbeits.med.

uni-muenchen.de

Accepted 1 February 2001

\begin{abstract}
Objectives-To describe the relation between spirometric findings and farming characteristics and variables of exposure to organic dust measured during work in animal buildings. Farmers have traditionally been described as having one of the most dangerous occupations, so a large scale study on European farmers was carried out. This is the report of the second part of that study.

Methods-40 pig farmers in Denmark and 36 poultry farmers in Switzerland were chosen randomly and were assessed over 1 working day.

Results-Mean (SD) baseline spirometric results in pig farmers were higher than in poultry farmers (forced expiratory volume in 1 second $\left(\mathrm{FEV}_{1}\right)$ (\% of reference value) $108.3(16.7) v 100.2(14.2) ; p=0.04)$. Baseline lung function results were significantly associated with ventilation of the animal houses. Furthermore, temperature was related to spirometric findings in pig farmers.

Conclusions-Ventilation of the animal house and temperature might influence respiratory morbidity in farmers.

(Occup Environ Med 2001;58:405-410)
\end{abstract}

Keywords: ventilation; micro-organism; European multicentre study

As early as 1555 Olaus Magnus recognised the health hazards of farmers connected with grain dusts. ${ }^{1}$ More recently epidemiological studies have indicated a greater risk of respiratory disorders in farmers than in non-farming occupations. ${ }^{23}$ It is known that animal farmers are exposed to organic dust, endotoxins, and

Table 1 Descriptive data and lung function values of pig and poultry farmers

\begin{tabular}{lccc}
\hline & Pig farmers & Poultry farmers & p Value \\
\hline & $n(\%)$ & $n(\%)$ & Fisher \\
Number & 40 & 36 & \\
Male sex & $36(90)^{\star}$ & $24(67)$ & 0.02 \\
Current smokers & $9(23)$ & $11(31)$ & 0.45 \\
Ex-smokers & $11(28)$ & $5(14)$ & 0.17 \\
Asthma symptomst & $2(5)$ & $3(9)$ & 0.66 \\
Symptoms of chronic bronchitis $\ddagger$ & $1(3)$ & $4(14)$ & 0.15 \\
Work related respiratory symptoms & $20(50)$ & $21(58)$ & 0.50 \\
& Mean (SD) & Mean (SD) & $t$ Test \\
Age (y) & $39(10)$ & $41(13)$ & 0.69 \\
Duration of work as a farmer (y) & $20(10)$ & $20(14)$ & 0.78 \\
FVC before exposure (\% ref value) & $107.0(14.1)$ & $101.4(14.9)$ & 0.13 \\
FVC after exposure (\% ref value) & $110.2(15.7)$ & $102.6(14.0)$ & 0.04 \\
FEV $_{1}$ before exposure (\% ref value) & $108.3(16.7)$ & $100.2(14.2)$ & 0.04 \\
FEV $_{1}$ after exposure (\% ref value) & $114.3(17.0)$ & $101.0(13.6)$ & $<0.001$ \\
MMEF $_{25 / 75}$ before exposure (\% ref value) & $101.7(25.0)$ & $88.8(20.4)$ & 0.02 \\
MMEF $_{25 / 75}$ after exposure (\% ref value) & $108.4(28.3)$ & $89.1(22.2)$ & 0.003 \\
\hline
\end{tabular}

${ }^{\star}$ Number in parenthesis $=\%$ of total population.

+Woken by an attack of shortness of breath during the past year, asthma attack during the past year, or currently taking medication for asthma.

$\ddagger$ Cough and phlegm on most days for at least 3 months during the preceding year. hazardous gaseous exposures. These substances may affect one or more parts of the respiratory system of farmers and may induce diseases such as allergic and non-allergic rhinitis, ${ }^{4}$ organic dust toxic syndrome (ODTS), ${ }^{5}$ bronchitis, ${ }^{6}$ asthma, ${ }^{1}$ and asthma-like syndrome. ${ }^{1}$

Hence, a European multicentre study on prevalence and risk factors of airway obstruction in farmers ${ }^{7}$ was carried out in seven centres in five countries (Denmark, Great Britain, Germany, Switzerland, Spain). In the first part of the study a questionnaire survey on general and work related respiratory symptoms relative to type of farming was carried out on 7752 randomly selected farmers. Pig, cattle, poultry, and sheep farmers, who worked in animal houses were shown to be at highest risk of developing respiratory symptoms. Although poultry farmers showed a significantly higher prevalence of wheezing, in farmers working with housed pigs the prevalence of asthma-like syndrome was significantly higher than in farmers not working with those animals. ${ }^{8}$ Because this first stage of the study showed that pig and poultry farmers were at highest risk of developing respiratory symptoms it was decided to study them in more detail.

Therefore, it was the aim of this second part of the survey to investigate the relation between lung function and measures of exposure and farming characteristics. A subsample of pig farmers was chosen in Denmark, and in Switzerland a population of poultry farmers was investigated. To be able to compare the measurements identical methodological approaches were used in both countries.

\section{Material and methods}

STUDY POPULATION

Out of the seven centres participating in the first part of this European study, we decided in the second part to study a subsample of randomly chosen animal farmers in the Danish and Swiss centres in more detail. During the first part of the study, 2002 farmers in Denmark (Arhus region; response rate 80.6\%) and 1542 farmers in Switzerland (Zurich region; response rate $81.6 \%$ ) answered a detailed questionnaire on respiratory symptoms and farming characteristics. Farmers were selected at random from the most recently available census (census of professional farmers organisations in Denmark, state census in Switzerland). ${ }^{8}$ Because in Denmark the group of farmers at highest risk of developing respiratory symptoms were pig farmers, ${ }^{8} 40$ pig farmers were chosen randomly from the target population. In Switzerland, the prevalence of work related respiratory symptoms was highest in poultry farmers ${ }^{89}$; therefore, 36 poultry 
Table 2 Univariate associations between farm characteristics, environmental measurements, and lung function results for pig farmers (mean (SD))

\begin{tabular}{|c|c|c|c|c|c|}
\hline & & $n$ & $\begin{array}{l}\text { FVC } \\
\% \text { Ref value }\end{array}$ & $\begin{array}{l}F E V_{1} \\
\% \text { Ref value }\end{array}$ & $\begin{array}{l}M M E F_{25 / 75} \\
\% \text { Ref value }\end{array}$ \\
\hline Automatic feeding & $\begin{array}{l}\text { No } \\
\text { Yes }\end{array}$ & $\begin{array}{r}8 \\
22\end{array}$ & $\begin{array}{l}107.6(14.3) \\
106.8(14.4)\end{array}$ & $\begin{array}{l}103.4(18.4) \\
110.1(16.1)\end{array}$ & $\begin{array}{r}82.9(21.2)^{\star \star} \\
108.2(23.1)\end{array}$ \\
\hline Storage time liquid manure $>1$ months & $\begin{array}{l}\text { No } \\
\text { Yes }\end{array}$ & $\begin{array}{r}25 \\
5\end{array}$ & $\begin{array}{l}106.3(14.8) \\
110.5(10.8)\end{array}$ & $\begin{array}{l}107.5(17.8) \\
112.4(9.4)\end{array}$ & $\begin{array}{l}100.5(26.3) \\
107.8(17.6)\end{array}$ \\
\hline Air inlet: porous inlet & $\begin{array}{l}\text { No } \\
\text { Yes }\end{array}$ & $\begin{array}{l}17 \\
13\end{array}$ & $\begin{array}{l}106.5(15.3) \\
107.6(12.9)\end{array}$ & $\begin{array}{l}107.1(17.5) \\
109.9(16.1)\end{array}$ & $\begin{array}{r}99.7(23.6) \\
104.3(27.6)\end{array}$ \\
\hline Control: humidity sensor & $\begin{array}{l}\text { No } \\
\text { Yes }\end{array}$ & $\begin{array}{l}12 \\
18\end{array}$ & $\begin{array}{l}101.0(15.7)^{\star} \\
111.0(11.7)\end{array}$ & $\begin{array}{l}100.7(18.9)^{\star} \\
113.4(13.2)\end{array}$ & $\begin{array}{r}90.8(19.6)^{\star} \\
108.5(26.0)\end{array}$ \\
\hline Heating & $\begin{array}{l}\text { No } \\
\text { Yes }\end{array}$ & $\begin{array}{r}2 \\
28\end{array}$ & \multicolumn{3}{|c|}{$\begin{array}{l}\text { Number of farmers without heating in the pig house was } \\
\text { too low }\end{array}$} \\
\hline Total dust $\geqslant$ median $\left(4.0 \mathrm{mg} / \mathrm{m}^{3}\right)$ & $\begin{array}{l}\text { No } \\
\text { Yes }\end{array}$ & $\begin{array}{l}15 \\
16\end{array}$ & $\begin{array}{l}111.2(14.9) \\
103.3(12.7)\end{array}$ & $\begin{array}{l}110.4(15.6) \\
106.6(17.9)\end{array}$ & $\begin{array}{l}100.5(26.0) \\
102.7(24.8)\end{array}$ \\
\hline $\begin{array}{l}\text { Endotoxin content in total dust } \geqslant \text { median }(58.0 \\
\left.\mathrm{ng} / \mathrm{m}^{3}\right)\end{array}$ & $\begin{array}{l}\text { No } \\
\text { Yes }\end{array}$ & $\begin{array}{l}15 \\
16\end{array}$ & $\begin{array}{l}104.9(12.8) \\
109.1(15.5)\end{array}$ & $\begin{array}{l}105.1(18.2) \\
111.6(15.0)\end{array}$ & $\begin{array}{r}99.4(30.1) \\
104.0(18.9)\end{array}$ \\
\hline Total fungi $\geqslant$ median $\left(8.7^{\star} 10^{6} / \mathrm{m}^{3}\right)$ & $\begin{array}{l}\text { No } \\
\text { Yes }\end{array}$ & $\begin{array}{l}14 \\
17\end{array}$ & $\begin{array}{l}106.6(14.3) \\
107.3(14.4)\end{array}$ & $\begin{array}{l}105.7(19.2) \\
110.6(14.4)\end{array}$ & $\begin{array}{r}93.0(29.2) \\
108.8(18.8)\end{array}$ \\
\hline Total bacteria $\geqslant$ median $\left(4.2^{\star} 10^{8} / \mathrm{m}^{3}\right)$ & $\begin{array}{l}\text { No } \\
\text { Yes }\end{array}$ & $\begin{array}{l}14 \\
17\end{array}$ & $\begin{array}{l}105.9(14.0) \\
107.9(14.6)\end{array}$ & $\begin{array}{l}105.1(19.0) \\
111.2(14.4)\end{array}$ & $\begin{array}{r}95.2(29.9) \\
107.0(19.5)\end{array}$ \\
\hline Ammonia $\geqslant$ median $(6 \mathrm{ppm})$ & $\begin{array}{l}\text { No } \\
\text { Yes }\end{array}$ & $\begin{array}{l}14 \\
17\end{array}$ & $\begin{array}{l}108.2(16.6) \\
106.1(12.3)\end{array}$ & $\begin{array}{l}108.2(16.8) \\
108.4(17.1)\end{array}$ & $\begin{array}{l}101.2(25.2) \\
102.0(25.6)\end{array}$ \\
\hline $\mathrm{CO}_{2} \geqslant$ median $(1200 \mathrm{ppm})$ & $\begin{array}{l}\text { No } \\
\text { Yes }\end{array}$ & $\begin{array}{l}14 \\
17\end{array}$ & $\begin{array}{l}109.7(16.1) \\
104.6(12.1)\end{array}$ & $\begin{array}{l}111.8(15.9) \\
105.3(17.2)\end{array}$ & $\begin{array}{l}102.6(17.5) \\
100.8(30.3)\end{array}$ \\
\hline Temperature $\geqslant$ median $\left(19.9^{\circ} \mathrm{C}\right)$ & $\begin{array}{l}\text { No } \\
\text { Yes }\end{array}$ & $\begin{array}{l}15 \\
16\end{array}$ & $\begin{array}{l}113.4(12.3)^{\star} \\
101.4(13.5)\end{array}$ & $\begin{array}{c}118.0(11.7)^{\star \star} \\
99.9(16.0)\end{array}$ & $\begin{array}{c}115.0(19.8)^{\star \star} \\
89.1(23.1)\end{array}$ \\
\hline Air humidity $\geqslant$ median $(75 \%)$ & $\begin{array}{l}\text { No } \\
\text { Yes }\end{array}$ & $\begin{array}{l}17 \\
14\end{array}$ & $\begin{array}{l}102.5(11.9) \\
112.1(15.1)\end{array}$ & $\begin{array}{l}105.3(11.3) \\
111.8(21.2)\end{array}$ & $\begin{array}{l}103.1(19.0) \\
100.0(31.5)\end{array}$ \\
\hline Air velocity $\geqslant$ median $(0.23 \mathrm{~m} / \mathrm{s})$ & $\begin{array}{l}\text { No } \\
\text { Yes }\end{array}$ & $\begin{array}{l}15 \\
16\end{array}$ & $\begin{array}{l}107.8(15.0) \\
106.2(13.7)\end{array}$ & $\begin{array}{l}108.4(16.5) \\
108.3(17.5)\end{array}$ & $\begin{array}{r}98.2(22.2) \\
104.9(27.6)\end{array}$ \\
\hline
\end{tabular}

${ }^{\star} \mathrm{p}<0.05 ;{ }^{\star \star} \mathrm{p}<0.01, U$ test.

farmers were randomly selected from the list of the regional professional farmers' organisation. Combinations of the main type of production with other types of animal or plant farming were documented but were not a selection criteria.

QUESTIONNAIRE

An inventory of farm characteristics was taken by visiting the farm and interviewing the participants about number and kind of animals, heating and ventilation system, type of floor, frequency of cleaning, and location of air exhaust. A special type of ventilation is porous ventilation-porous walls or ceilings. This is characterised by big porous surfaces with plenty of small holes-for example, mineral wool or perforated plates. In animal houses with automatic ventilation, the ventilation flow is mostly controlled by a temperature sensor. A particular type of automatic ventilation control is regulation through humidity sensors, used in houses where supplementary heat is needed. In these buildings a humidity sensor is used in addition to the temperature sensor. This means that the indoor temperature is controlled by the temperature sensor, which influences the air exchange in the animal house; if the indoor relative air humidity increases above the set level, additional heat is supplied. Subsequently the temperature rises and the ventilation flow increases.
Structured interviews were additionally performed with questions on respiratory symptoms within the preceding year, smoking habits, and standardised questions on chronic bronchitis (British Medical Research Council criteria). Asthma was defined as having been woken by an attack of shortness of breath during the past year, reporting at least one asthma attack during the past year, or currently taking asthma medication. Subjects reporting cough and phlegm on most days for at least 3 months during the preceding year were defined as having chronic bronchitis. Special emphasis was given to respiratory symptoms during work that suggested airway narrowing or irritation (shortness of breath, wheezing, and dry cough). In both study centres identical questionnaires were used with some adaptation to the specific kind of animal. The questionnaires were tested for comprehensibility and translated, with back translation into English.

LUNG FUNCTION TESTS

Lung function tests were performed immediately before and after feeding the animals in the morning by two thoroughly trained technicians in both centres. A portable spirometer (Denmark: Flowscreen II, Jaeger, Wuerzburg, Germany; Switzerland: MultiSPIRO-PC, Biotrine, Woburn, MA, USA) was used after daily calibration. Forced vital capacity (FVC), forced expiratory volume in 1 second $\left(\mathrm{FEV}_{1}\right)$, 
and midexpiratory flow rate $\left(\mathrm{MMEF}_{25 / 75}\right)$ were measured. All results were analyzed blindly by the same person (GP) according to the American Thoracic Society standardisation criteriathat is, of three acceptable flow-volume curves the largest and the second largest values of FVC and $\mathrm{FEV}_{1}$ values were not allowed to vary by more than $200 \mathrm{ml}$ or $10 \%$. The $\mathrm{MMEF}_{25 / 75}$ values were recorded from the manoeuvre with the largest sum of $\mathrm{FEV}_{1}$ and FVC. ${ }^{11}$ Lung function results were compared with reference values after adjustment for age and height as proposed by the European Community for Steel and $\mathrm{Coal}^{12}$ and given as a percentage of the reference value. The decline in lung function variables over the feeding period was calculated as a percentage of the baseline value. As measurements were taken before and after exposure in all subjects, each person served as his or her own control.

ENVIRONMENTAL MEASUREMENTS

Personal monitors were used to collect samples for each farmer during the daily work inside the animal buildings resulting in a median sampling time of 118 minutes. Farmers carried out their usual tasks during measurements wearing the personal pumps while moving from one building to another. The samples collected were analyzed for total dust, endotoxin concentration in total dust, and microbial contamination (total bacteria and fungi). Dust was collected on preweighed (Technischer Überwachungsverein (TÜV) Hanover, Germany), 37 $\mathrm{mm}$ diameter glass fibre filters (SKC, Müllheim, Germany) fixed in threaded holders (GSP, Personal air sampler, GSA Meßgerätebau Neuss, Germany) with a constant airflow 3.5 1/min (224 PCXR 7 KB, SKC, Müllheim, Germany). Dust concentration was measured gravimetrically (lower detection limit $0.09 \mathrm{mg} /$ filter) and related to air volume. Endotoxin content of dust samples was measured by a kinetic-turbidimetric limulus assay as described by Hollander et $a l^{13}$ in the laboratory of the Institute of Animal Hygiene and Animal Welfare (School of Veterinary Medicine, Hanover, Germany). Results were related to air volume and expressed as $\mathrm{ng} / \mathrm{m}^{3}$ (EC 6 standard, 8 EU=1 ng, lower detection limit $0.005 \mathrm{EU})$. Airborne micro-organisms were collected on polycarbonate filters with a pore size of $0.4 \mu \mathrm{m}$ and a diameter of $25 \mathrm{~mm}$ placed on cellulose support pads and sealed in presterilised carbon filled polypropylene air monitoring cassettes (Pegasus Labor, Duesseldorf, Germany) with an airflow of 1 1/min (224 PCXR 7KB, SKC, Muellheim, Germany). The total concentration of airborne microorganisms was measured by the CAMNEA method $^{14}$ with an epifluorescence microscope.

Also, a point measurement of ammonia (Ammonia 5/a, CH 20501, 5 - 70 ppm, Draeger Sicherheitstechnik, Luebeck, Germany), carbon dioxide (Carbon Dioxide 100/a, 81 01811, 100 3000 ppm; Draeger Sicherheitstechnik, Luebeck, Germany), temperature, air humidity, and

Table 3 Univariate associations between farm characteristics and lung function results for poultry farmers (mean (SD))

\begin{tabular}{|c|c|c|c|c|c|}
\hline & & $n$ & $\begin{array}{l}\text { FVC } \\
\% \text { Ref value }\end{array}$ & $\begin{array}{l}F E V_{1} \\
\% \text { Ref value }\end{array}$ & $\begin{array}{l}M M E F_{25 / 75} \\
\% \text { Ref value }\end{array}$ \\
\hline Automatic feeding & $\begin{array}{l}\text { No } \\
\text { Yes }\end{array}$ & $\begin{array}{r}1 \\
35\end{array}$ & \multicolumn{3}{|c|}{$\begin{array}{l}\text { Number of farmers without automatic feeding in the } \\
\text { poultry house was too low }\end{array}$} \\
\hline Storage time liquid manure $>1$ months & $\begin{array}{l}\text { No } \\
\text { Yes }\end{array}$ & $\begin{array}{l}16 \\
20\end{array}$ & $\begin{array}{r}96.9(13.4) \\
105.0(15.4)\end{array}$ & $\begin{array}{r}96.9(13.7) \\
102.8(14.3)\end{array}$ & $\begin{array}{l}88.9(20.7) \\
88.7(20.7)\end{array}$ \\
\hline Air inlet: porous inlet & $\begin{array}{l}\text { No } \\
\text { Yes }\end{array}$ & $\begin{array}{l}15 \\
21\end{array}$ & $\begin{array}{c}108.5(15.8)^{\star} \\
96.4(12.2)\end{array}$ & $\begin{array}{r}105.3(13.1) \\
96.6(14.1)\end{array}$ & $\begin{array}{l}87.5(15.2) \\
89.7(23.9)\end{array}$ \\
\hline Control: humidity sensor & $\begin{array}{l}\text { No } \\
\text { Yes }\end{array}$ & $\begin{array}{r}34 \\
2\end{array}$ & \multicolumn{3}{|c|}{$\begin{array}{l}\text { Number of farmers with humidity sensor in the } \\
\text { poultry house was too low }\end{array}$} \\
\hline Heating & $\begin{array}{l}\text { No } \\
\text { Yes }\end{array}$ & $\begin{array}{l}22 \\
13\end{array}$ & $\begin{array}{l}100.3(11.7) \\
103.9(19.8)\end{array}$ & $\begin{array}{r}99.3(12.9) \\
102.6(16.6)\end{array}$ & $\begin{array}{l}87.8(18.5) \\
91.1(24.3)\end{array}$ \\
\hline Total dust $\geqslant$ median $\left(7.0 \mathrm{mg} / \mathrm{m}^{3}\right)$ & $\begin{array}{l}\text { No } \\
\text { Yes }\end{array}$ & $\begin{array}{l}16 \\
16\end{array}$ & $\begin{array}{r}99.6(14.3) \\
105.8(15.9)\end{array}$ & $\begin{array}{r}98.2(12.9) \\
103.2(15.9)\end{array}$ & $\begin{array}{l}87.8(20.0) \\
86.6(17.5)\end{array}$ \\
\hline Endotoxin content in total dust $\geqslant$ median $\left(257.6 \mathrm{ng} / \mathrm{m}^{3}\right)$ & $\begin{array}{l}\text { No } \\
\text { Yes }\end{array}$ & $\begin{array}{l}16 \\
17\end{array}$ & $\begin{array}{l}101.9(15.5) \\
102.7(15.3)\end{array}$ & $\begin{array}{l}100.4(13.9) \\
100.6(15.0)\end{array}$ & $\begin{array}{l}87.5(16.3) \\
86.9(20.2)\end{array}$ \\
\hline Total fungi $\geqslant$ median $\left(2.0^{\star} 10^{7} / \mathrm{m}^{3}\right)$ & $\begin{array}{l}\text { No } \\
\text { Yes }\end{array}$ & $\begin{array}{l}18 \\
18\end{array}$ & $\begin{array}{l}101.6(13.0) \\
101.3(17.0)\end{array}$ & $\begin{array}{r}100.7(13.8) \\
99.7(15.0)\end{array}$ & $\begin{array}{l}88.1(22.3) \\
89.5(18.8)\end{array}$ \\
\hline Total bacteria $\geqslant$ median $\left(4.7^{\star} 10^{9} / \mathrm{m}^{3}\right)$ & $\begin{array}{l}\text { No } \\
\text { Yes }\end{array}$ & $\begin{array}{l}18 \\
18\end{array}$ & $\begin{array}{l}101.5(14.6) \\
101.3(15.6)\end{array}$ & $\begin{array}{r}100.8(15.2) \\
99.6(13.5)\end{array}$ & $\begin{array}{l}90.3(20.9) \\
87.2(20.3)\end{array}$ \\
\hline Ammonia $\geqslant$ median $(12 \mathrm{ppm})$ & $\begin{array}{l}\text { No } \\
\text { Yes }\end{array}$ & $\begin{array}{l}17 \\
19\end{array}$ & $\begin{array}{r}103.8(12.8) \\
99.3(16.6)\end{array}$ & $\begin{array}{r}101.4(12.8) \\
99.1(15.6)\end{array}$ & $\begin{array}{l}89.6(22.5) \\
88.0(18.8)\end{array}$ \\
\hline $\mathrm{CO}_{2} \geqslant \operatorname{median}(2100 \mathrm{ppm})$ & $\begin{array}{l}\text { No } \\
\text { Yes }\end{array}$ & $\begin{array}{l}16 \\
19\end{array}$ & $\begin{array}{r}104.3(11.0) \\
99.5(17.8)\end{array}$ & $\begin{array}{r}101.3(10.7) \\
99.9(16.9)\end{array}$ & $\begin{array}{l}85.1(17.4) \\
92.2(22.8)\end{array}$ \\
\hline Temperature $\geqslant$ median $\left(16.2^{\circ} \mathrm{C}\right)$ & $\begin{array}{l}\text { No } \\
\text { Yes }\end{array}$ & $\begin{array}{l}18 \\
18\end{array}$ & $\begin{array}{r}98.7(11.5) \\
104.2(17.6)\end{array}$ & $\begin{array}{r}97.9(12.6) \\
102.5(15.6)\end{array}$ & $\begin{array}{l}89.1(19.3) \\
88.4(21.9)\end{array}$ \\
\hline Air humidity $\geqslant$ median $(71 \%)$ & $\begin{array}{l}\text { No } \\
\text { Yes }\end{array}$ & $\begin{array}{l}18 \\
18\end{array}$ & $\begin{array}{r}103.7(11.5) \\
99.1(17.6)\end{array}$ & $\begin{array}{r}100.8(11.2) \\
99.6(17.0)\end{array}$ & $\begin{array}{l}87.0(19.4) \\
90.6(21.8)\end{array}$ \\
\hline Air velocity $\geqslant$ median $(0.01 \mathrm{~m} / \mathrm{s})$ & $\begin{array}{l}\text { No } \\
\text { Yes }\end{array}$ & $\begin{array}{r}1 \\
34\end{array}$ & \multicolumn{3}{|c|}{$\begin{array}{l}\text { Number of farmers with air velocity }<\text { median in the } \\
\text { poultry house was too low }\end{array}$} \\
\hline
\end{tabular}

${ }^{\star} \mathrm{p}<0.05, U$ test. 
Table 4 Environmental measurements

\begin{tabular}{lllc}
\hline & $\begin{array}{l}\text { Pig farmers } n=40 \\
\text { Median (range) }\end{array}$ & $\begin{array}{l}\text { Poultry farmers } n=36 \\
\text { Median }(\text { range) }\end{array}$ & $\begin{array}{l}p \text { Value } \\
\text { (Mann-Whitney } \\
\text { U test) }\end{array}$ \\
\hline Total dust $\left(\mathrm{mg} / \mathrm{m}^{3}\right)$ & $4.0(1.1-13.8)$ & $7.0(0.4-21.8)$ & $<0.001$ \\
Endotoxin content in total dust $\left(\mathrm{ng} / \mathrm{m}^{3}\right)$ & $58.0(1.3-1101.7)$ & $257.6(19.0-1634.8)$ & $<0.001$ \\
Total fungi $\left(\mathrm{n} / \mathrm{m}^{3}\right)$ & $8.7 \times 10^{6}\left(<\mathrm{DL}-1.4 \times 10^{8}\right)$ & $2.0 \times 10^{7}\left(<\mathrm{DL}-1.1 \times 10^{9}\right)$ & 0.02 \\
Total bacteria $\left(\mathrm{n} / \mathrm{m}^{3}\right)$ & $4.2 \times 10^{8}\left(<\mathrm{DL}-1.6 \times 10^{9}\right)$ & $4.7 \times 10^{9}\left(2.70^{\star}-4.2 \times 10^{10}\right)$ & $<0.001$ \\
Ammonia $(\mathrm{ppm})$ & $6(<\mathrm{DL}-14)$ & $12(<\mathrm{DL}-40)$ & 0.02 \\
$\mathrm{CO}_{2}(\mathrm{ppm})$ & $1200(800-2500)$ & $2100(600-4100)$ & $<0.001$ \\
Temperature $\left({ }^{\circ} \mathrm{C}\right)$ & $19.9(15.9-22.3)$ & $16.2(4.2-25.4)$ & $<0.001$ \\
Air humidity $(\%)$ & $75(60-86)$ & $71(54-96)$ & 0.10 \\
Air velocity $(\mathrm{m} / \mathrm{s})$ & $0.23(0.06-0.52)$ & $0.01(0.00-0.29)$ & $<0.001$ \\
\hline
\end{tabular}

$\mathrm{DL}=$ detection limit.

air velocity (Testo 400, Testo, Lenzkirch, Germany) was performed in each of the animal houses under study. Details of the air sampling and laboratory analyses are described elsewhere. $^{10}$ In each centre only two people performed the measurements after thorough training by one of the authors (KR). All air quality measurements were evaluated by the same laboratories.

\section{ANALYSIS}

Data were analyzed with a statistical package for personal computers (Statistica, Tulsa, USA).

Descriptive data of the two study centres were compared by $t$ tests for continuous variables and Fisher's exact test for nominal data. The $t$ test for dependent variables was used to compare lung function before and after feeding. Data on lung function of farmers with workplace exposure less than the median (0) or greater than or equal to the median (1) of all samples from each centre were compared by Mann-Whitney $U$ test. Only variables with at least five results/group were compared. Also, significant results in the univariate analyses were analysed with multiple linear regression analysis adjusting for smoking (pack-years).

Differences in farming methods and levels of exposure between symptomatic (wheezing, breathlessness, or cough without phlegm at work) and asymptomatic farmers were tested with Fisher's exact test and $t$ test for independent variables.

\section{Results}

SUBJECTS

The two study groups were comparable for age, duration of work on a farm, prevalence of respiratory symptoms, and smoking (table 1) although the number of male farmers was significantly higher among pig farmers than poultry farmers. Comparing the lung function results before and after work inside the animal houses, pig farmers had significantly higher results than poultry farmers $(\mathrm{p}<0.05, t$ test $)$ in all spirometric variables, except for FVC

Table 5 Decline in mean (SD) lung function over the feeding period in the morning (\% of baseline value) for all farmers, farmers with, and farmers without work related respiratory symptoms

\begin{tabular}{llll}
\hline Respiratory variable & Total $(n=67)$ & $\begin{array}{l}\text { With work related } \\
\text { symptoms }\end{array}$ & $\begin{array}{l}\text { Without work related } \\
\text { symptoms }(n=36)\end{array}$ \\
\hline$\Delta \mathrm{FVC}$ & $-1.52(6.12)$ & $-1.25(6.61)$ & $-1.83(5.58)$ \\
$\Delta \mathrm{FEV}_{1}$ & $-1.73(6.17)$ & $-0.88(6.73)$ & $-2.72(5.38)$ \\
$\Delta \mathrm{MMEF}_{25 / 75}$ & $-1.63(12.52)$ & $-0.84(12.11)$ & $-2.50(13.12)$ \\
\hline
\end{tabular}

^Work related symptoms: wheezing, breathlessness, or cough without phlegm at work. percentage of the reference value in the morning $(p=0.13, t$ test). Lung function results after work inside the animal buildings did not differ significantly from the values before exposure ( $p>0.05$, paired sample $t$ test) for either pig or poultry farmers.

ASSOCIATIONS BETWEEN FARM CHARACTERISTICS AND BASELINE LUNG FUNCTION RESULTS

Tables 2 and 3 show that farming characteristics were significantly associated with lung function results before the feeding period for pig (table 2) and poultry farmers (table 3). A negative influence of ventilation control without a humidity sensor in the pig houses was found for all lung function variables. Pig farmers who used automatic feeding showed significantly higher $\mathrm{MMEF}_{25 / 75}$ percentage of reference value than farmers without. In poultry houses the presence of a porous air inlet was significantly negatively associated with results of FVC. All results were confirmed after adjusting for pack-years of smoking (data not shown).

ASSOCIATIONS BETWEEN ENVIRONMENTAL MEASUREMENTS AND SPIROMETRIC RESULTS

Environmental measurements of exposure were significantly higher in poultry than in pig houses (table 4 ).

Comparing lung function results of farmers with workplace exposure less than the median with farmers with workplace exposure greater than or equal to the median, pig farmers with higher temperatures inside the pig house had significantly lower lung function results (table 2 ). This was also confirmed after adjustment for pack-years of smoking (data not shown). No relation between environmental measurements and baseline lung function could be established for poultry farmers (table 3).

\section{SYMPTOMATIC AND ASYMPTOMATIC FARMERS}

Farmers not complaining of work related respiratory symptoms (wheezing, breathlessness, or cough without phlegm at work) had significantly higher results for $\mathrm{FEV}_{1}$ percentage of reference value (108.2 (15.1) v 100.1 (15.6); $\mathrm{p}<0.05, t$ test) and $\mathrm{MMEF}_{25 / 75}$ percentage of reference value (100.9 (23.8) v 89.5 (22.0); $\mathrm{p}<0.05, t$ test) than farmers with symptoms. The trend towards an increase in lung function over the feeding period was greater in asymptomatic than in symptomatic farmers (table 5). No significant differences in age, duration of farm work, or measures of exposure were found 
between farmers with work related respiratory symptoms and farmers without such symptoms. Also, farming characteristics did not differ significantly between symptomatic and asymptomatic farmers.

\section{Discussion}

The three main findings of this study were (a) lower lung function in poultry farmers than pig farmers, $(b)$ factors related to work in the housed areas of pigs and poultry (variables of ventilation and feeding management) were significantly associated with decrements in lung function, and (c) higher temperatures inside the pig houses were significantly negatively associated with lung function in pig farmers.

To our knowledge, no study has been published on the link between specific characteristics of poultry farming and impairment of lung function. Two studies are known, which focused on pig buildings, ${ }^{15}{ }^{16}$ but only one study, by Vogelzang et al, used environmental measurements as well as questionnaire data. ${ }^{17}$

The limitation of our study was the low number of pig and poultry farmers in each centre. To detect farming characteristics resulting in small changes in lung function higher numbers of farmers would be needed to get sufficient statistical power. Nevertheless, we have shown that variables of ventilation and feeding might be related to changes in lung function. The finding of our study that ventilation could be an important factor in the development of occupational airway disease in farmers is compatible with data from previous studies of Bongers et al, ${ }^{16}$ Vogelzang et al, ${ }^{15} 17$ and Donham, ${ }^{18}$ as well as our earlier study on cattle farmers. ${ }^{19}$ In our study of cattle farmers we also detected a negative influence of heating on respiratory symptoms, which is compatible with our finding that higher temperatures might have a negative influence on lung function in pig farmers. The associations between ventilation and heating may indicate that higher temperatures throughout the year and lower rates of exchange of air may result in higher concentrations of endotoxins, glucans, and mites in animal houses and thus in higher respiratory morbidity among farmers. Preller et $a l^{20}$ have shown that besides other variables, type of heating, ventilation, and feeding as a task are associated with high exposure of dust and endotoxin in pig buildings. Comparing exposure variables of ventilation through porous inlets to poultry houses with different ventilation systems we found that ventilation through porous inlets had higher concentrations of fungi, bacteria, ammonia, and $\mathrm{CO}_{2}$ (data not shown). Also, in pig buildings ventilation control through a humidity sensor and lower temperatures were associated with reduced overall exposure. Therefore, ventilation and temperature might be proxies of total exposure inside the buildings.

As in our study on exposure characteristics in pig and poultry buildings, ${ }^{10}$ some previous investigations have shown higher exposure in poultry houses than in pig buildings. ${ }^{21-23}$ Other than this, no studies have yet been published comparing lung function of pig and poultry farmers. As shown in our study, poultry farmers did not only have a higher exposure to environmental factors such as dust, endotoxin, and micro-organisms, but also showed lower mean lung function results. To confirm our findings lung function measurements should be performed in pig and poultry farmers from one country with one spirometer to diminish the geographical differences between the farmers and to minimise technical confounders.

No significant change in lung function values was found over the feeding period. This lack of change is probably due to the circadian rhythm of lung function values with lowest values in the early morning and highest in the afternoon. ${ }^{24}$ Other studies have shown a significant decline over the feeding period in pig farmers ${ }^{25}$ and poultry workers ${ }^{26}$ but it has to be borne in mind that the median exposure time in our study was only 118 minutes. Farmers in the study of Donham et $a l^{25}$ had to stay out of the building for at least 48 hours before the testing. In poultry farmers, Thelin et $a l^{27}$ found a mean decrease in $\mathrm{FEV}_{1}$ of $0.11 \mathrm{l}$ in an exposure period of 1 working day. In our study it was impossible to obtain longer exposure periods because the farmers normally work only for a short time in the morning and in the evening inside the animal houses. Nevertheless, there was a tendency towards a lower increase in $\mathrm{FEV}_{1}$ over the feeding period in the symptomatic farmers, as was found in other surveys. ${ }^{25} 28$

In this study, a low standard of ventilation control inside the animal houses was related to long term impairment of lung function. Prospective cohort studies including a larger number of poultry farmers are warranted to estimate the effects of farming characteristics on respiratory health in more detail.

We thank the farmers for their participation. We are especially thankful to Jan Ove Johnsen and Thorkild Jensen who performed the Danish measurements, to Jörg Hartung who carried out the endotoxin analysis and to Georg Praml who analyzed the lung function results. We also thank Brian Leaderer for language assistance and his helpful comments. This study was supported by the European Union (BMH1-CT94-1554), Swiss National Science Foundation (NF 3200-045997.95/1), BBW Switzerland (93.0283), and Lieselotte und Dr Karl Otto Winkler-Stiftung für Arbeitsmedizin.

1 American Thoracic Society. Schenker MB. Respiratory health hazards in agriculture. Am $\mathcal{F}$ Respir Crit Care Med 1998;158:S1-76

2 Kogevinas M, Anto JM, Sunyer J, et al. Occupational asthma in Europe and other industrialised areas: a populationbased study. Lancet 1999;353:1750-4.

3 Senthilselvan A, Dosman JA, Kirychuk SP, et al. Accelerated lung function decline in swine confinement workers. Chest 1997;111:1733-41.

4 Terho EO, Husman K, Vohlonen I. Prevalence and incidence of chronic bronchitis and farmer's lung with respect to age, sex, atopy, and smoking. Eur 7 Respir Dis Suppl to87:152:19-28.

5 Melbostad E, Eduard W, Magnus P. Chronic bronchitis in farmers. Scand $\mathcal{f}$ Work Environ Health 1997;23:271-80.

6 Rask-Andersen A. Organic dust toxic syndrome among armers. Br F Ind Med 1989;46:233-8.

7 Nowak D. Prevalence and risk factors for airway diseases in farmers: a new EC multicentre project. Ann Agric Environ Med 1994;1:81-2.

8 Radon K, Danuser B, Iversen M, et al. Respiratory symptoms in European animal farmers. Eur Respir $\mathcal{F}$ (in press).

9 Danuser B, Weber C, Künzli N, et al. Respiratory symptoms in Swiss farmers: an epidemiological study of risk factors. Am $\mathcal{f}$ Ind Med (in press).

Am f Ind $M$.
10 Withdrawn.

10 American Thoracic Society Standardization of spirometry. 1994 Update. Am f Respir Crit Care Med 1995;152:1107-36. 
12 Quanjer PH, Tammeling GJ, Cotes JE, et al. Lung volumes and forced ventilatory flows. Report working party standardization of lung function tests, European Community for Steel and Coal. Official statement of the European Respiratory Society. Eur Respir f 1993;16(suppl): 5-40.

13 Hollander A, Heederik D, Verslot P, et al. Inhibition and enhancement in the analysis of airborne endotoxin levels in various occupational environments. Am Ind Hyg Assoc $\mathcal{F}$ 1993;54:647-53.

14 Palmgren U, Ström G, Blomquist G, et al. Collection of airborne microorganims on Nuclepore filters, estimation and analysis: CAMNEA method. F Appl Bact 1986;61: 401-6.

15 Vogelzang PFJ, van der Gulden JWJ, Preller L, et al. Respiratory morbidity in relationship to farm characteristics in swine confinement work: possible preventive measures. Am f Ind Med 1996;30:212-18.

16 Bongers P, Houthuijs D, Remijn B, et al. Lung function and respiratory symptoms in pig farmers. $\mathrm{Br} f$ Ind $\mathrm{Med}$ 1987;44:819-23.

17 Vogelzang PFJ, van der Gulden JWJ, Preller L, et al. Bronchial hyperresponsiveness and exposure in pig farmers. Int Arch Occup Environ Health 1997;70:327-33.

18 Donham KJ. Association of environmental air contaminants with disease and productivity in swine. Am F Vet Res 1991; 10:1723-30.

19 Radon K, Opravil U, Hartung J, et al. Work-related respiratory disorders and farming characteristics among cattle farmers in Northern Germany. Am $\mathcal{F}$ Ind Med 1999;36: $444-9$
20 Preller L, Heederik D, Kromhout H, et al. Determinants of dust and endotoxin exposure of pig farmers: development of a control strategy usin

21 Seedorf J, Hartung J, Schröder M, et al. Concentration and emissions of airborne endotoxins and microorganisms in ivestock buidlings in Northern Europe. Fournal of Agricultural Engineering Research 1998;70:97-109.

22 Takai H, Pedersen S, Johnsen JO, et al. Concentrations and emissions of airborne dust in livestock buildings in Northern Europe. Fournal of Agricultural Engineering Research 1998;70:59-77.

23 Clark S, Rylander R, Larsson L. Airborne bacteria, endotoxin and fungi in dust in poultry and swine confinement buildings. Am Ind Hyg Assoc 7 1983;44:537-41.

24 Wegner R, Nern E, Poschadel B, et al. Tagesrhythmik von Lungenfunktionsme $\beta$ werten unter Berücksichtigung des Geschlechts und Rauchverhaltens. Arbeitsmed Sozialmed Umweltmed 1997;32:43-8.

25 Donham KJ, Zavala DC, Merchant J. Acute effects of the work environment on pulmonary functions of swine work environment on pulmonary functions of
confinement workers. Am f Ind Med 1984;5:367-75.

26 Donham KJ, Cumro D, Reynolds SJ, et al. Dose-response relationships between occupational aerosol exposures and cross-shift declines of lung function in poultry workers: recommendation for exposure limits. F Occup Environ Med 2000;42:260-9.

27 Thelin A, Tegler O, Rylander R. Lung reactions during poultry handling related to dust and bacterial endotoxin levels. Eur F Respir Dis 1984;65:266-71.

28 Zuskin E, Zagar Z, Schachter EN, et al. Respiratory symptoms and ventilatory capacity in swine confinement workers. Br F Ind Med 1992;49:435-40.

\section{ANSWERS (See page $\mathbf{4 2 4}$ for questions)}

(1) (a) False (b) True $(c)$ False $(d)$ True $(e)$ True $(f)$ False $(g)$ False

(2) (a) False (b) False (c) True (d) True (e) False

(3) (a) True (b) True (c) True (d) False (e) True ( $f$ ) True

(4) (a) False (b) True (c) False (d) False (e) False 